\title{
Diagnosis of study habits in second and fourth semester students of upper secondary level
}

\section{Diagnóstico de hábitos de estudio en estudiantes de segundo y cuarto semestre de nivel medio superior}

\author{
SESENTO, Leticia' \& LUCIO, Rodolfo" \\ 'Colegio Primitivo y Nacional de San Nicolás de Hidalgo, Mexico. \\ "Universidad Michoacana de San Nicolás de Hidalgo, Faculty of Veterinary Medicine and Zootechnics, Mexico.
}

ID $1^{\text {st }}$ Author: Leticia, Sesento / ORC ID: 0000-0002-6456-058X, Researcher ID Thomson: S-6997-2018, CVU CONACYT ID: 449302

ID $1^{\text {st }}$ Coauthor: Rodolfo, Lucio / ORC ID: 0000-0002-0535-3652, Researcher ID Thomson: X-2391-2018, CVU CONACYT ID: 947303

DOI: $10.35429 / J E H W .2020 .7 .4 .1 .6$

Received July 15, 2020; Accepted December 30, 2020

\begin{abstract}
Currently, students are received in high school without study habits that influence appropriate academic performance, this has a great influence on their transition to the upper secondary level. It is important to note that study habits are the behaviors and activities that students perform frequently. The current era is determined by globalization and the preponderance of the new economy where the important element is the knowledge society, for this reason continuous education and the development of competencies to "learn to learn" are transcendental; it is essential to promote study habits. It is a descriptive cross-sectional study through surveys. To carry out this research, a simple stratified sampling was carried out with second and fourth semester students from the Colegio Primitivo y Nacional de San Nicolás de Hidalgo of the Universidad Michoacana. The sample is made up of 151 students. Study habits test, consists of 20 items. The results obtained in this research lead to approve that second and fourth semester students do not have sufficient study habits. Through academic tutorials, it is proposed to carry out a program that allows students to develop attitudes and skills for study. Carry out programs to support them through experiences taught at the Faculty of Psychology, called Personal Growth Workshop and Life and Career Planning, which would benefit them by working in group therapy, setting personal goals. It is recommended that teachers encourage the development of positive study habits in the different academic activities planned, executed and evaluated. Develop talks on planning and organization of time, use of study techniques and management of educational resources. On the part of the tutors, aimed at students in whom inappropriate study habits and attitudes are detected.
\end{abstract}

Students, Upper secondary level, Study habits

\begin{abstract}
Resumen
Actualmente se reciben en el bachillerato estudiantes sin los hábitos de estudio que influyan en el rendimiento académico apropiado, esto tiene gran influencia en su tránsito en el nivel medio superior. Es importante destacar que los hábitos de estudios, son las conductas y actividades que realizan los estudiantes de manera frecuente. La época actual se determina por la globalización y la preponderancia de la nueva economía donde el elemento importante es la sociedad del conocimiento, por tal motivo resulta trascendental la educación continua y el desarrollo de competencias para "aprender a aprender"; es fundamental impulsar los hábitos de estudio. Es un estudio descriptivo transversal mediante encuestas. Para efectuar la presente investigación se realizó un muestreo simple estratificado con estudiantes de segundo y cuarto semestre del Colegio Primitivo y Nacional de San Nicolás de Hidalgo de la Universidad Michoacana. La muestra se encuentra compuesta por 151 estudiantes. Test de hábitos de estudio, consta de 20 ítems. Los resultados obtenidos en la presente investigación conllevan aprobar que los estudiantes de segundo y cuarto semestre no cuentan con los suficientes hábitos de estudio. A través de las tutorías académicas se propone realizar un programa que permita desarrollar en los estudiantes actitudes y aptitudes para el estudio. Efectuar programas para apoyarlos a través de experiencias que se imparten en la Facultad de Psicología, llamadas Taller de Crecimiento Personal y Planeación de vida y Carrera, que los beneficiaría al trabajar terapia grupal, proponiéndose metas personales. Se recomienda que los docentes incentiven el desarrollo de hábitos positivos de estudio en las diferentes actividades académicas planificadas, ejecutadas y evaluadas. Desarrollar charlas sobre planificación y organización del tiempo, empleo de técnicas de estudio y manejo de recursos educativos. Por parte de los profesores tutores dirigido a los estudiantes en los que se detecten inadecuados hábitos y actitudes de estudio.
\end{abstract}

Estudiantes, Nivel medio superior, Hábitos de estudio

Citation: SESENTO, Leticia \& LUCIO, Rodolfo. Diagnosis of study habits in second and fourth semester students of upper secondary level. Journal Health, Education and Welfare. 2020. 4-7:1-6.

\footnotetext{
* Correspondence to Author (Email: leticiasesentogarcia@yahoo.com.mx)

$\dagger$ Researcher contributing first author.
} 


\section{Introduction}

In the Nicolaita high school of the Michoacana University of San Nicolás de Hidalgo (UMSNH), the students do not report enough study habits that allow them to move skillfully to the higher level; among other variables that act on educational lag and school dropout. High school students are determined to be in a transition period, which is adolescence, a scenario that complicates their stay and, above all, the attention to their subjects they take, they do not perceive them as a context that will benefit them for their life future, during their stay in high school and in their professional life.

On the other hand, if students are provided with the foundations to form study habits that allow them, be more competitive and develop their intellectual capacity, the skills of the future profession and the attitudes to develop professionally, substantial elements will coexist for an excellent school exercise. It is important to note that modern society requires universities, which forge an appropriate development in their graduates, this will be achieved to the extent that professionals who are competent in the workplace are established, that from their training the student has the necessary tools to Stand up to the challenges and be trained in the operational area, which is why it is considered of great importance that they be considered from the early stages of training in our university students.

University life is a stage of great changes, students face various personal, social, professional transformations, etc. The important thing is to develop in them decision-making, control of their emotions, recognition of their potentials, etc., and it is through university tutoring that we want to locate and affirm students throughout the process of adaptation to university life, accompany along their university path, guide, motivate and support their integral development.

\section{Developing}

Currently, students are received in high school without study habits that influence appropriate academic performance, this has a great influence on their transition to the upper secondary level.
Poves (2007) shows that the study habit is an exercise that is carried out every day around the same time, the recurrence of this behavior in time forms an instinctive device that conceives it possible and effective. The student constitutes her time and space; uses certain methods and technologies that he uses to study It is important to note that study habits are the behaviors and activities that students perform frequently, it is essential to note that it is the usual practice of trying to prepare continuously.

For this reason, "success in studying not only depends on intelligence and effort, but also on the effectiveness of study habits" (Maddox, 2004). Cited in (Colmenero 2012, p.3). This work proposes making a diagnosis of study habits in second and fourth semester students as part of the group tutoring activities, at least one hour a week, so that students develop favorable study habits to take advantage of the contents of the subjects that are taught, since study habits are substantial at different stages in professional training.

\section{Theoretical framework}

At the international level, the high level of university students with academic problems has been the motivation to seek better approaches to instruct, where the student plays the main role in the "teaching-learning" process, an attempt has been made to update the tutorial system, which You can do different types of university tutoring, however careful investigation of the different teaching theories is required to be really effective and the problem of study habits that university students show can be noticed. At the national level, it can be found lately that there are situations that cause some students to enter universities with deficiencies in their preparation, these are identified with individual and establishment factors, such as society, family, the educational system and the classroom . This referring to the success of a student, will always be related to the habits they have. There is research that shows the treatment of study habits and university tutoring that show that the university student is not receiving a good university tutoring; on the other hand, the study habits of university students are not being carried out in optimal environmental conditions, they do not have adequate and personalized schedules, which does not allow them to organize themselves properly. 
It also presents difficulties in the use of materials, due to the fact that it improperly handles study techniques and presents limitations in the assimilation of content, not endorsing the content or personalizing it.

The current era is determined by globalization and the preponderance of the new economy where the important element is the knowledge society, for this reason continuous education and the development of competencies to "learn to learn" is transcendental; It is essential to promote study habits, which facilitate the appropriation of new knowledge that allow students to be competitive.

\section{Study habits}

Study habits according to Vinent (2006) should be understood as the continuous repetition of an act, which makes it possible to achieve positive results in learning and where factors such as interest and internal motivation of the learning student intervene and which are manifested by the fact, firstly, that students misuse them, and secondly, that they lack them (cited in Cruz, 2011, p.2).

The theoretical foundations that support study habits are framed within the cognitive approach, which focuses on how the subjects perceive, interpret, store and remember information, who are considered active entities capable of intervening in their process, consider that the Learning is an active summary that includes the use of strategies and experiences that are transformed into new categories and organized conceptions.

According to Wrenn (2003), study habits constitute the disposition acquired by the constant exercise of individuals to apply actions that allow them to read, take notes, concentrate, distribute time and work effectively. On the other hand, study attitudes.

For Candela (2017), the study habit is the way in which the student deals with their academic activities every day. Which means that it is the natural practice of trying to develop constantly, this means that the student is structured in the period, scope and useful procedures for the study (p. 24).
It is important to highlight that the theoretical foundations that support the study habits are framed from the cognitive perspective, which focuses its attention on how the subjects perceive, interpret, store and remember the information, who are considered as active subjects trained to intervene in their process, they reflect that learning is an active process that perceives the use of strategies and practices that become new categories and established conceptions. Another aspect to consider is study attitudes.

\section{Study attitudes}

In relation to the attitudes in the study, these are emotional states that vary according to the maturation and learning experiences of the individual, they are the mood expressed externally, in addition to expressing the way in which the state of mind is communicated to the rest of the people. According to Horna (2007), attitudes predispose the individual to act positively or negatively in the face of different stimuli or circumstances.

They influence their approach and avoidance behavior towards other people, events and ideas and also their concepts about the physical and social world. Attitudes are not static by themselves, on the contrary, they can be modified, this explains the fact that the student may have a certain inclination towards a teacher, subject or friendship and for some reason reject it later.

According to Meenes (2005), two of the main factors that explain the academic achievement achieved by a student are the study method and the attitudes to study. Regarding attitudes, he mentions that if the student shows positive or adequate attitudes, he will generally concentrate his attention on the stimulating and satisfactory aspects of academic activity, on wanting to study, on having serious motivations that maintain the effort, as well as the will to study and concentration on tasks; On the other hand, if the student's attitude is negative or inappropriate, she will only focus on unpleasant aspects such as study materials, the teacher who teaches the subject, classmates, the timetable, among others; which will affect their academic achievement. 
Regarding the attitudes for the study Meenes (2005) mentions that the student with inappropriate attitudes will only focus on unpleasant aspects such as study materials, the teacher who teaches the subject, classmates, the schedule, etc. which can affect your academic performance.

\section{Methodology}

It is a descriptive cross-sectional study through surveys, since the variables are not manipulated by looking naturally at the phenomena or facts. To carry out this research, a simple stratified sampling was carried out with second and fourth semester students from the Colegio Primitivo y Nacional de San Nicolás de Hidalgo of the Universidad Michoacana. The sample is made up of 151 second and fourth semester students from a population of 310 students consisting of $49 \%$ of the population under study from the Colegio Primitivo y Nacional de San Nicolás de Hidalgo.

\section{Description of the instrument}

Study habits test, admits to appreciate and detail study habits; it will be possible to detect students who may be at risk of failing, dropping out or delaying their terminal efficiency, which can be administered in groups and / or individually, in an average time of 15 minutes, consists of 20 items.

\section{Analysis of results}

The age of the students was $48 \% 16$ years old, $24 \% 15$ years old, $24 \% 17$ years old, $1 \% 14$ years old, 18 years old $2 \%$ and finally 19 years old $1 \%$. She surveyed $49 \%$. The bias in the sample does not exist, since $49 \%$ of the total population of the second and fourth semesters were selected through simple stratified sampling. The percentage according to gender was: $63 \%$ female and $36 \%$ male.

Among the most outstanding results are the following:

Regarding the questioning if you study periodically and not just before the exam?

$46 \%$ of students study from time to time, while $28 \%$ study almost always, $8 \%$ always, $14 \%$ almost never and finally $4 \%$ never.
Another aspect to consider in the review was Do you sleep 7 to 8 hours regularly?

$33 \%$ of the students mentioned that they get 7-8 hours of sleep regularly from time to time; Likewise, $30 \%$ of these mention that they almost always sleep from 7 to 8 hours; on the other hand, $16 \%$ always sleep between 7 and 8 hours; in the same way, $15 \%$ report that they never sleep from 7 to 8 hours and definitely $6 \%$ never.

Regarding the question, Do you do physical activity periodically?

$32 \%$ of students do physical activities all the time, $30 \%$ almost always, $26 \%$ occasionally, $11 \%$ almost never and $1 \%$ definitely do not.

In relation to the question about whether, is your diet considered healthy?

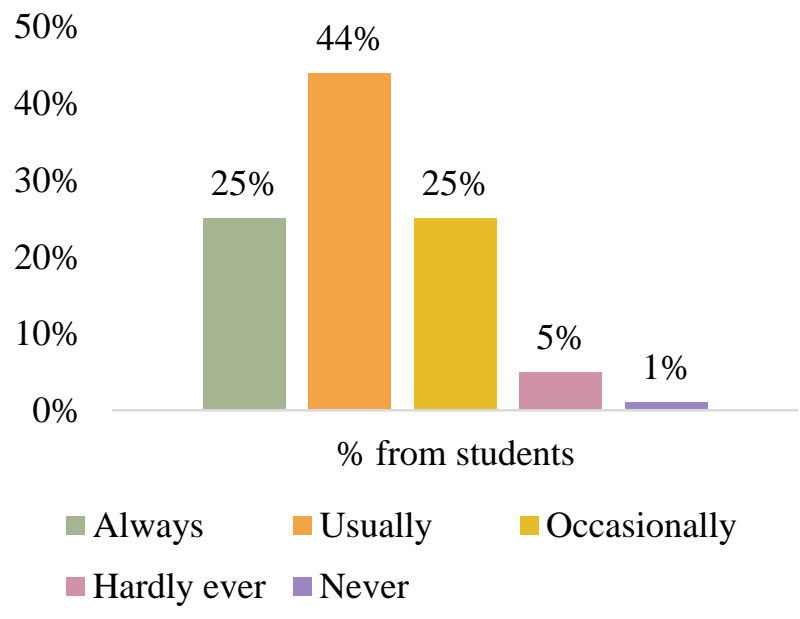

$25 \%$ of the students indicate that they always have a healthy diet, while $44 \%$ almost always, on the other hand $25 \%$ of the students from time to time and finally $1 \%$ suggest never having a healthy diet.

In relation to questioning, do you procrastinate using other activities as a refuge so as not to face the study?

$39 \%$ of students mention that from time to time, while $20 \%$ report that almost always, $5 \%$ students report that always, $21 \%$ almost never and finally $15 \%$ report that they never.

SESENTO, Leticia \& LUCIO, Rodolfo. Diagnosis of study habits in second and fourth semester students of upper secondary level. Journal Health, Education and Welfare. 2020 


\section{Conclusions}

In general terms, the second and fourth semester students of the Colegio de San Nicolás de Hidalgo do not have enough study habits and attitudes. It is important to continue the work on study habits since they report that it is an activity that they do little on a regular basis. For Horna (2007), attitudes are not static by themselves, on the contrary, they can change. For this reason, it is important to carry out programs that allow them to improve study habits. For which it is proposed to optimize the academic performance of high school students.

On the other hand, the regulation of the times they sleep is important to let them know that it corresponds to sleep regularly from 7 to 8 hours in a normal way. Healthy eating is another activity to work with students, in the same way doing physical activities.

It is essential to carry out a diagnosis of study habits with those who enter high school since this will allow them to know strengths, weaknesses and opportunities. Corresponding to these, carry out tutorial action programs. Strengthen study habits with courses workshops, prepared by experts from the Faculty of Psychology with whom we work and research through a Network of Academic Bodies.

Through academic tutorials, it is proposed to carry out a program that allows students to develop attitudes and aptitudes for study. And express in a pertinent way students with low evaluations, low academic performance or with particular difficulties, to underpin through practices that are shared in the Faculty of Psychology, called Personal Growth Workshop and Life and Career Planning, which would favor them when working group therapy, based on personal goals.

It is necessary for upper secondary level students to refer with training areas such as study circles and self-learning workshops that facilitate the acquisition and strengthening of appropriate study habits. In the same way, it is recommended that teachers

It is recommended that teachers promote the progress of positive study habits in the different academic actions planned, carried out and evaluated.
Develop talks on planning and organization of time, use of study techniques and management of educational resources; by the tutor teachers aimed at students in whom inappropriate study habits and attitudes are detected, as well as the use of these to improve their proposed time to their studies to achieve an excellent academic result.

\section{References}

Aduna, M., \& Marquez, S. (1987). Curso de hábitos de estudio y autocontrol. México: Trillas S.A.

Alfonso, S. (2006). Estudio Analítico del Rendimiento Estudiantil a Través del Cumplimiento de los Planes de Evaluación por Parte de los Docentes del IUT "José A. Anzoátegui, Universidad Pedagógica Experimental Libertador, Instituto Pedagógico de Maturín.

Candela, L (2017). Hábitos de estudio, motivación y aprendizaje de las matemáticas en estudiantes de la Universidad Privada de los Andes 2016 (Tesis de maestría). Universidad Cesar Valle, Perú.

Colmenero (2012). Incidencia de los hábitos de estudio en el proceso de aprendizaje de alumnos de educación primaria en la inteligencia emocional

file://C:/Users/letic/Downloads/DialnetIncidenciaDeLosHabitosDeEstudioEnElProces oDeApred-4644902\%20(4).pdf.

Cruz, F. (2011) Hábitos de estudio, actitudes y autoestima relacionados con rendimiento académico en estudiantes de enfermería. https://www.eumed.net/rev/ced/23/fcn.htm

De Mézerville (2006). Ejes de la salud mental. Los procesos de autoestima, dar y recibir afecto y adaptación al estrés. México: Trillas.

Hernández, R., Fernández, C. y Baptista, P. (2004). Metodología de la investigación. México: Mac Graw Hill.

Hernández, F. (2005). Métodos y técnicas de estudio en la universidad. Colombia: Mc Graw Hill.

Horna, R. (2007) Aprendiendo a Disfrutar del Estudio. Perú. Ed. Renalsa. 
Maddox, H. (2004). Como estudiar. Barcelona: Oikos Tau.

Maslow, A. (1985). El hombre autorrealizado: hacia una psicología del ser. Buenos Aires: Troquel.

Meenes. M. (2005). Como estudiar para aprender. Buenos Aires, Argentina. Ed. Paidós. Melillo, A. (2005). La Resiliencia. Buenos Aires.Editorial Paidós.

Núñez C. y Sánchez J.(2005) Hábitos de Estudio y Rendimiento Académico. Pontificia Universidad Católica de Chile. Santiago de Chile.

Poves M. (2007). Hábitos de Estudio y el Rendimiento Académico. España. Ed. Tarancón Quevedo, E. (2006). Rasgos de continuidad del rendimiento académico. Lima: Pontificia Universidad Católica del Perú.

Rice (2007). Adolescencia, desarrollo, relaciones y cultura. Madrid: Prentice: Hall.

Ribeiro, L., (2006). Desarrollo humano. Barcelona. Ediciones Odisea.

Rogers, C. (2001). El proceso de convertirse en persona. México: Paidós.

Santrock, J. (2007). Psicología de la educación. México. Mc Graw Hill.

Tapia, I. (2005). Métodos y Técnicas de Estudio. Lima. Ed. Corito.

Touron, J. (2005). Factores del rendimiento académico en la universidad. España: Universidad de Navarra.

Vinent, R (2006). Introducción a la metodología del estudio. Barcelona. Editorial Mitre. 